\title{
Most small bowel cancers are revealed by a complication
}

\section{A maioria dos cânceres de intestino delgado são revelados por uma complicação}

\author{
Ionut Negoi ${ }^{1,2}$, Sorin Paun ${ }^{1,2}$, Sorin Hostiuc ${ }^{1}$, Bodgan Stoica ${ }^{2}$, Ioan Tanase ${ }^{2}$, \\ Ruxandra Irina Negoi ${ }^{1}$, Mircea Beuran ${ }^{1,2}$
}

\begin{abstract}
Objective: To characterize the pattern of primary small bowel cancers in a tertiary East-European hospital. Methods: A retrospective study of patients with small bowel cancers admitted to a tertiary emergency center, over the past 15 years. Results: There were 57 patients with small bowel cancer, representing $0.039 \%$ of admissions and $0.059 \%$ of laparotomies. There were $37(64.9 \%)$ men, mean age of 58 years; and 72 years for females. Out of 57 patients, 48 (84.2\%) were admitted due to an emergency situation: obstruction in 21 $(38.9 \%)$, perforation in $17(31.5 \%)$, upper gastrointestinal bleeding in $8(14.8 \%)$, and lower gastrointestinal bleeding in $2(3.7 \%)$. There were $10(17.5 \%)$ duodenal tumors, $21(36.8 \%)$ jejunal tumors and $26(45.6 \%)$ ileal tumors. The most frequent neoplasms were gastrointestinal stromal tumor in 24 patients $(42.1 \%)$, adenocarcinoma in $19(33.3 \%)$, lymphoma in $8(14 \%)$, and carcinoids in $2(3.5 \%)$. The prevalence of duodenal adenocarcinoma was 14.55 times greater than that of the small bowel, and the prevalence of duodenal stromal tumors was 1.818 time greater than that of the small bowel. Obstruction was the complication in adenocarcinoma in $57.9 \%$ of cases, and perforation was the major local complication $(47.8 \%)$ in stromal tumors. Conclusion: Primary small bowel cancers are usually diagnosed at advanced stages, and revealed by a local complication of the tumor. Their surgical management in emergency setting is associated to significant morbidity and mortality rates.
\end{abstract}

Keywords: Intestine, small/pathology; Neoplasms; Emergencies

\section{RESUMO}

Objetivo: Caracterizar o padrão de neoplasias malignas primárias do intestino delgado em um hospital terciário de Leste Europeu. Métodos: Estudo retrospectivo de pacientes com câncer de intestino delgado, internados em um hospital terciário e de emergência, ao longo dos últimos 15 anos. Resultados: Foram avaliados 57 pacientes com neoplasias malignas gastrintestinais, 0 que representou $0,039 \%$ das admissões e 0,059\% das laparotomias realizadas. Total de 37 (64,9\%) pacientes masculinos, média de idade de 58 anos, e de 72 anos para mulheres. Dentre os 57 pacientes, $48(84,2 \%)$ foram internados em situação de emergência: obstrução intestinal em 21 (38,9\%), perfuração em $17(31,5 \%)$, hemorragia digestiva alta em $8(14,8 \%)$, e hemorragia digestiva baixa em $2(3,7 \%)$. Houve $10(17,5 \%)$ tumores duodenais, $21(36,8 \%)$ jejunais e $26(45,6 \%)$ ileais. As neoplasias mais frequentes foram tumor estromal gastrintestinal, em $24(42,1 \%)$ pacientes, adenocarcinoma em $19(33,3 \%)$, linfoma em $8(14 \%)$ e carcinoides em $2(3,5 \%)$. A prevalência de adenocarcinoma duodenal foi 14,55 vezes maior do que a do intestino delgado, e a prevalência de tumores estromais duodenais foi 1,818 vez maior do que a do intestino delgado. A obstrução intestinal foi complicação do adenocarcinoma em $57,9 \%$ dos casos, e a perfuração foi a principal complicação local $(47,8 \%)$ dos tumores estromais. Conclusão: As neoplasias malignas primárias do intestino delgado foram geralmente diagnosticadas em estado avançado e reveladas por uma complicação local do tumor. 0 tratamento cirúrgico em situação de emergência está associado à significativa morbimortalidade.

Descritores: Intestino delgado/patologia; Neoplasias; Emergências

\section{INTRODUCTION}

Malignant tumors of the small bowel are extremely rare, and account to, in average, approximately 2 to $3 \%$ of gastrointestinal cancers. ${ }^{(1-3)}$ The estimated new cases per year and the estimated mortality is 5,300 and 1,210,

\footnotetext{
${ }^{1}$ Carol Davila University of Medicine and Pharmacy Bucharest, Bucharest, Romania.

2 Emergency Hospital of Bucharest, Bucharest, Romania.

Corresponding author: Ionut Negoi - No 8 Floreasca Street, Sector 1 - Zip code: 014461 - Bucharest, Romania - Phone: +40 723209910 - E-mail: negoiionut@gmail.com

Received on: Apr 28, 2015 - Accepted on: Aug 19, 2015

Conflict of interest: none.

DOI: 10.1590/\$1679-45082015A03380
} 
respectively, in the United States, and 3,500 and 1,100, respectively, in Europe. ${ }^{(4)}$ Their incidence increased during the last decades, and in roughly one third of cases they are associated with prior or subsequent other tumor of the gastrointestinal tract. ${ }^{(5)}$ More than 40 different histopathological types of neoplasm occur in the small bowel, but over $95 \%$ of malignancy are adenocarcinomas, gastrointestinal stromal tumors (GIST), carcinoids or lymphomas. The diagnosis of these tumors is often delayed due to their nonspecific symptoms, usually being made during an acute complication of the disease. In a symptomatic stage more than $50 \%$ of cases present metastatic disease. ${ }^{(6)}$ Knowing the nonspecificity of the clinical picture, only a high index of suspicion may offer an early diagnosis and treatment. The reported overall 5-year survival rate was $83 \%$ for carcinoids, $25 \%$ for adenocarcinomas, $62 \%$ for lymphomas and $45 \%$ for stromal tumors. ${ }^{(7)}$ However, the combined 5-year relative overall survival improved from 32.5 to $66.9 \%$, between 1975 and 2006. ${ }^{(8)}$ Out of all the periampullary tumors, duodenal adenocarcinomas have the best prognosis, with a 5-year survival of $32.8 \%$, comparing with pancreatic head adenocarcinoma which has a 5 -year survival of only $6.5 \% .^{(9)}$ Overall, advanced small bowel adenocarcinoma had a worse prognosis than colorectal cancer, but better than gastric or pancreatic tumors. ${ }^{(10)}$

\section{OBJECTIVE}

The main objective of this study was to characterize the pattern of small bowel primary cancers managed in a tertiary, university affiliated, emergency center. The secondary objectives were to determine early morbidity and mortality associated with surgical resection, and to correlate the pathology of the tumor with its clinical picture.

\section{METHODS}

Retrospective study of adult patients, males and females, admitted in our hospital over the past 15 years. The selection criteria were duodenal, jejunal or ileal tumor; and histopathological examination proving the small bowel malignant neoplasm. Continuous variables are expressed as mean \pm standard deviation, and the categorical ones as number (percent). Categorical variables were compared by the $\chi^{2}$ tests. The distribution of continuous variables was evaluated by KolmogorovSmirnov test and one-way Analisys of Variance (ANOVA).
The $t$-test or the nonparametric tests (Mann-Whitney U or Kruskal-Wallis H tests) were used for independent samples. The probability of rejecting the null hypothesis (statistical significance) was set at 0.05 . For statistical analysis we used IBM Statistical Package for the Social Science (SPSS) Statistics 20 software. We also did an electronic search at the databases of the U.S. National Library of Medicine, National Institutes of Health, PubMed/MEDLINE, EMBASE, Google Scholar, and ISI Web of Knowledge, to identify original articles and reviews about the subject. The terms "intestinal", "small bowel", "cancer" and "tumor" were used in various combinations. The keywords were identified as truncated words in the title, abstract or in Medical Subject Heading (MeSH). Only English language literature was selected for further analysis. Electronic and manual cross-referencing was used further to find more relevant sources.

\section{RESULTS}

There were 57 patients admitted during 15 years, accounting for $0.039 \%$ from our admissions and $0.059 \%$ from our laparotomies. There were 37 (64.9\%) males and $20(35.1 \%)$ females (95\% confidence interval: 95\% CI - female: $23 \%-48 \%$; males: $52 \%-77 \%)$. The mean age for males was $58 \pm 12.7$ years, and $68 \pm 16,20$ years for females (Figure 1). There were 10 (17.5\%) duodenal, 21 (36.8\%) jejunal and $26(45.6 \%)$ ileal tumors (Figure 2). Out of 57 patients, 48 (84.2\%) were admitted in emergency setting: obstruction with 21 (38.9\%) cases, perforation with $17(31.5 \%)$, upper gastrointestinal bleeding with $8(14.8 \%)$ and lower gastrointestinal bleeding with $2(3.7 \%)$. We observed a mean interval from onset of symptoms to surgical treatment of 73 days, with $2.2 \pm 1.32$ imaging tests per patient and $1.1 \pm 0.326$ prior hospital admissions for nonspecific abdominal symptoms.

The most common conditions were GIST (24/42.1\%), adenocarcinoma (19/33.3\%), lymphoma $(8 / 14 \%)$, and carcinoids $(7 / 10.6 \%)$ (Figure 3 ). The prevalence of duodenal adenocarcinoma was 14.55 times greater than that of the small bowel $(p=0.001)$, the prevalence of duodenal stromal tumors was 1.818 time greater than that of the small bowel $(p=0.001)$ (Figure 4).

Intestinal obstruction was the complication observed in adenocarcinoma in $57.9 \%$ of cases $(p=0.019)$, and tumor rupture was the main local complication (47.8\%) for GIST $(\mathrm{p}=0.024)$. The surgical approach for duodenal tumors was pancreatoduodenectomy (PD) in $80 \%$, tumorectomy in $10 \%$, and palliative by-pass in $10 \%$ of 


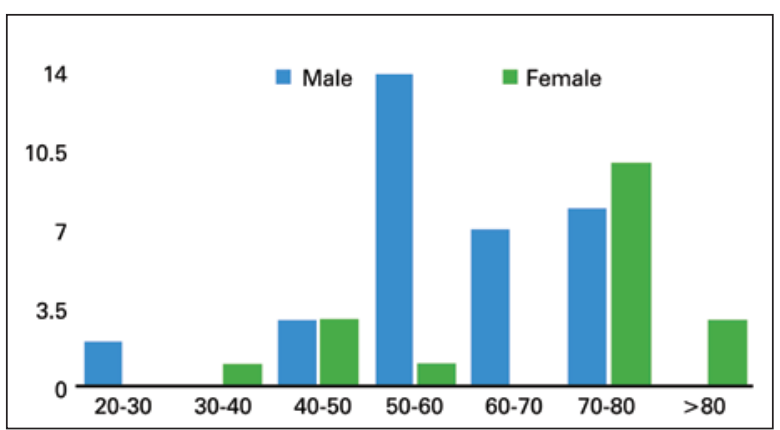

Figure 1. Age distribution of the patients

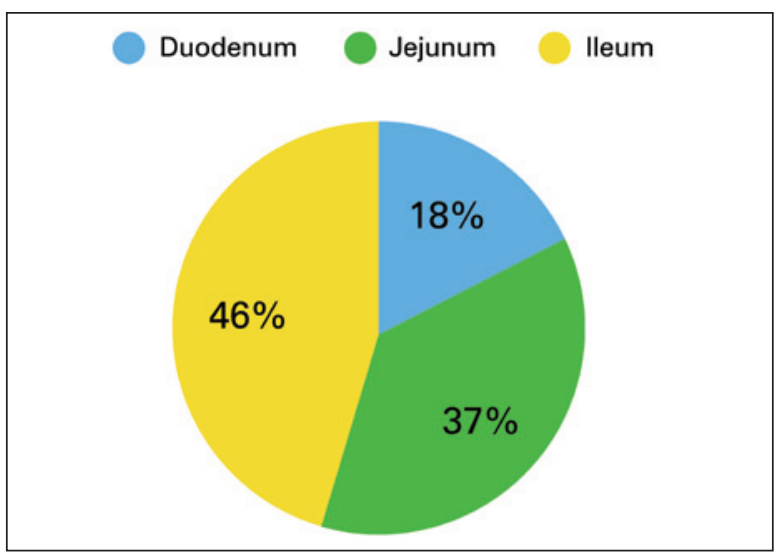

Figure 2. Localization of the small bowel tumor

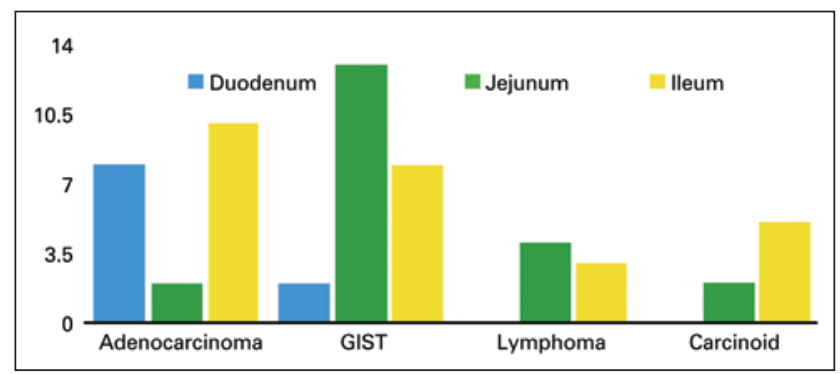

GIST: gastrointestinal stromal tumors

Figure 3. Histopathology of the tumor correlated with the location

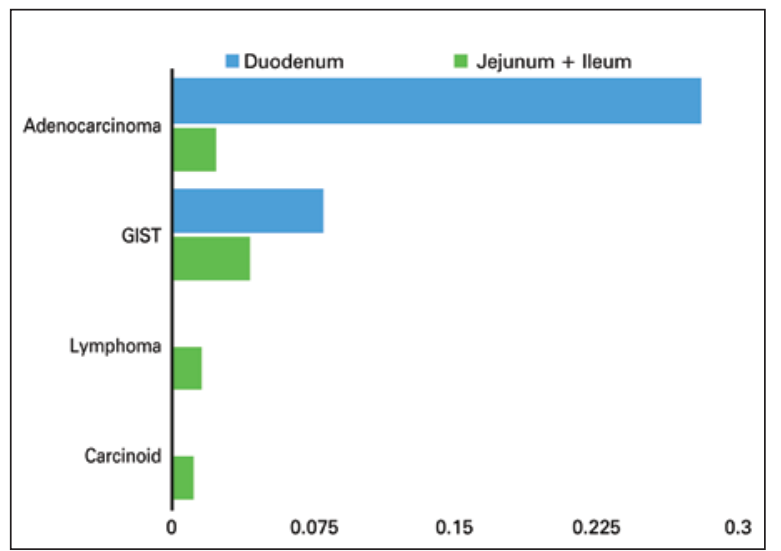

GIST: gastrointestinal stromal tumors.

Figure 4. The observed frequency of the small bowel tumors correlated with the anatomical length of the duodenum versus jejunum and ileum cases. PD for complicated duodenal cancers strongly correlates with a high mortality $(p=0.008)$. All cases of jejunal and ileal tumors were managed by intestinal resection with regional lymphadenectomy and primary anastomosis. We observed a 30-day mortality of $26 \%$.

\section{DISCUSSION}

Although the small bowel accounts for $75 \%$ of the length and $90 \%$ of the surface of the gastrointestinal tract, it very rarely presents malignancies. An explanation for this would be a more diluted content with less irritation of the mucosa, a rapid transit with a shorter exposure to the carcinogens, less bacterial flora with less conversion of the biliary acids into carcinogens, and an increased lymphoid tissue with a high local concentration of $\operatorname{IgA}$, differently from the colorectal region. ${ }^{(11,12)}$ The gut has an area of $300 \mathrm{~m}^{2}$, which is the largest barrier against the external environment, such as dietary components and the bacterial flora ${ }^{(13)}$ (Chart 1).

Chart 1. Predisposing conditions to small bowel cancer

\begin{tabular}{|lcr|}
\hline Risk factors & Tumor type & \\
\hline Small bowel adenoma ${ }^{(14,15)}$ & Adenocarcinoma & $\begin{array}{r}\text { Risk is more important for } \\
\text { increased size, higher dysplasia } \\
\text { grade and villous morphology }\end{array}$ \\
$\begin{array}{l}\text { Crohn's disease }{ }^{(16)} \\
\text { Coeliac disease }{ }^{(17,18)}\end{array}$ & $\begin{array}{c}\text { Adenocarcinoma } \\
\text { Adenocarcinoma } \\
\text { and lymphoma }\end{array}$ & $\begin{array}{c}\text { A relative risk of } 33 \\
\text { Hereditary non-polyposis risk for adenocarcinoma } \\
\text { of } 60-80\end{array}$ \\
$\begin{array}{l}\text { Familial adenomatous } \\
\text { polyposis }{ }^{(20)}\end{array}$ & Adenocarcinoma & A relative risk more than 100 \\
Peutz Jeghers syndrome & Adenocarcinoma & $3-5 \%$ will develop duodenal cancer \\
\hline
\end{tabular}

The intestinal epithelium has an enormous selfrenewing capacity, being completely replaced in 4 to 5 days. ${ }^{(22)}$ The carcinogenesis mechanisms seem to be related to the host-bacteria interaction, with secondary changes into the intestinal stem cell function, such as activation of the JAK-STAT, JNK and Wnt pathways. Chronic inflammation and hyperproliferation of the intestinal stem cells initiate malignant transformation, maintenance and metastases. ${ }^{(23)}$ Laforest et al. investigated the frequency of somatic mutations in 83 small bowel adenocarcinomas. ${ }^{(24)}$ These cases were selected from two European databases; in that, $47 \%$ of cases were duodenal tumors, and, in $63 \%$ of cases, there were three or more tumors. With a frequency over $5 \%$, there were mutations 
in Kras, TP53, APC, SMAD4, PIK3CA, BRAF, ERBB2, BRAF and FBXW7. ERBB2 mutations were present in $12 \%$ of patients, and significantly associated with duodenal tumor location. This study suggests that more than $10 \%$ of patients with small bowel adenocarcinoma may benefit from anti-ERBB2-targeted agent. ${ }^{(24)}$

Maglinte et al. investigated the reasons for primary malignancies of the small bowel being diagnosed so late. They found that the average delay is attributable, as follows: (a) if less than 2 months, to patients failing to report symptoms; (b) at 8.2 months, to physicians not ordering the appropriate diagnostic tests; (c) at 12 months, to the radiologist failing to make diagnosis. ${ }^{(25)}$ We observed in our patients a mean interval from onset of symptoms to diagnosis of 73 days.

An analysis of the Surveillance, Epidemiology, and End Results (SEER), from 1973 to 1982, showed that the incidence of the malignant carcinoid increased during this decade by $50 \% .^{(26)}$ Carcinoid tumors, lymphomas, and sarcomas were rarely located in the duodenum, while nearly half of the adenocarcinomas were found in this site. A total of $87 \%$ of carcinoids and $60 \%$ of lymphomas were in the ileum. ${ }^{(26)}$ The analysis of 67,843 patients, from the National Cancer Data Database (1985-2005) and SEER (1973-2004) showed that $37.4 \%$ were carcinoids, $36.9 \%$ adenocarcinomas, $8.8 \%$ stromal tumors, and $17.3 \%$ lymphomas. ${ }^{(27)}$ We have found similarities for the frequency of adenocarcinoma $(33.3 \%)$ and lymphoma (14\%), with a significantly larger number of GIST (42.1\%) and lesser for carcinoids $(10.6 \%)$. These differences may be due to our hospital profile, being a tertiary emergency center, with carcinoids presenting a longer indolent clinical course and a lower complication rate comparing to GIST.

From 1974 to 2004, the incidence of carcinoids increased more than four-fold, from 2.1 to 9.3 per million, while changes in adenocarcinoma, GIST and lymphoma were less significant. ${ }^{(27)}$ A population-based study from Swedish Cancer Register analyzed 6,604 patients with small bowel malignant tumors. ${ }^{(28)}$ During the study period, from 1960-2009, the incidence of the duodenal cancer increased more than three-fold, especially by a dramatically rising trend of adenocarcinoma of the duodenum. ${ }^{(28)}$ In a study analyzing the data from Western Canada, most adenocarcinomas $(54.7 \%)$ occurred in the duodenum, $29.9 \%$ in the jejunum and $16 \%$ in the ileum. ${ }^{(29)}$ There was an opposite trend for carcinoids, being located in only $3.9 \%$ of cases in duodenum, and in $9.2 \%$ in the jejunum and in $86.7 \%$ in ileum. The same disposition was for lymphomas: $21 \%$ in duodenum,
$29.4 \%$ in jejunum and $49.5 \%$ in the ileum. ${ }^{(29)}$ Looking at the frequency of the tumors per centimeter of the small bowel, we observed an incidence, at the level of the duodenum, 14.55 times higher for adenocarcinomas and 1.818 higher for GIST.

An analysis of 1,060 patients from Connecticut Tumor Registry showed that the most common location was the ileum (29.7\%), followed by duodenum (25.4\%) and jejunum $(15.3 \%)$. In $27.8 \%$ of cases the tumor location was not specified. ${ }^{(5)}$ We have found $17.5 \%$ duodenal tumors, $36.8 \%$ jejunal tumors and $45.6 \%$ ileal tumors.

Jejunal and ileal adenocarcinomas are best managed by wide segmental resection and regional lymphadenectomy. Right hemicolectomy is indicated for distal ileal tumor. Adenocarcinomas of the first and second duodenum should be addressed by PD, while tumors of the third and fourth duodenum through a pancreas sparing duodenal resection. ${ }^{(8)}$ For radical resections of the duodenal tumors we preferred PD in $80 \%$ of cases, while jejunal and ileal tumors were managed by segmental oncological resection with primary anastomosis in all cases.

Howe et al. reviewed the National Cancer Database, finding 4,995 patients with small bowel adenocarcinoma. ${ }^{(30)}$ The overall 5-year disease specific survival was 30.5\%, with a median survival of 19.7 months. Factors significantly correlated with disease specific survival were age, tumor site, disease stage, and whether cancer directed surgery was performed. The disease specific survival is reduced for duodenal adenocarcinoma compared with jejunal or ileal tumors. ${ }^{(30)}$ Sohn et al. investigated factors influencing long-term survival in 55 patients with duodenal adenocarcinomas. ${ }^{(31)}$ From 48 patients with radical resections there were $35 \mathrm{PD}$ and 13 pancreas-sparing duodenectomies. PD was associated with increased postoperative complications $(57 \%$ versus $30 \%$ ). The favorable factors for long-term survival were negative resection margins, PD and tumors in the first and second portions of the duodenum. ${ }^{(31)}$ The Cleveland Clinic group found the following negative prognostic factors for survival in adenocarcinoma of the small bowel: positive surgical margins, extramural venous spread, lymph node metastases, poor tumor differentiation, depth of tumor invasion, and history of Crohn's disease. ${ }^{(32)}$ As an adjuvant chemotherapeutic regimen it seems that the combination of capecitabine and oxaliplatin is highly effective for small bowel adenocarcinoma, with a median overall survival favoring chemotherapy for advanced jejunal or ileal tumors of 17 versus 8 months $(p=0.114)$. (33) Czaykowski and Hui reviewed the 10-year experience of the British Columbia Cancer Agency regarding the 
chemotherapy effect in small bowel adenocarcinoma. ${ }^{(34)}$ The chemotherapy was given to 21 of the 47 patients. Out of 19 patients treated with curative intent, 5 received adjuvant chemotherapy. The median overall survival for those who received palliative chemotherapy was 15.6 months versus 7.7 months $^{(34)}$ (Chart 2).

Chart 2. Studies evaluating chemotherapy in advanced small bowel adenocarcinoma

\begin{tabular}{|c|c|c|c|c|c|}
\hline Reference & Regimen & Number of patients & Response rate (\%) & $\begin{array}{c}\text { Progression- free survival } \\
\text { (months) }\end{array}$ & $\begin{array}{c}\text { Overall survival } \\
\text { (months) }\end{array}$ \\
\hline Crawley et al. ${ }^{(35)}$ & $5 F U$ & 8 & 37 & 7.8 & 13.0 \\
\hline Locher et al. ${ }^{(36)}$ & 5FU + cisplatin & 20 & 21 & 8.0 & 14.0 \\
\hline Gibson et al. ${ }^{\mid 37]}$ & 5FU + doxorubicin + MMC & 38 & 18 & 5.0 & 8.0 \\
\hline \multirow[t]{4}{*}{ Zaanan et al. ${ }^{(38)}$} & FOLFOX & 48 & 34 & 6.9 & 17.8 \\
\hline & LV5FU2 & 10 & 0 & 7.7 & 13.5 \\
\hline & LV5FU2 + cisplatin & 19 & 30 & 6.0 & 9.6 \\
\hline & FOLFIRI & 16 & 9 & 4.8 & 10.6 \\
\hline \multirow[t]{2}{*}{ Overman et al. ${ }^{(39)}$} & 5FU + cisplatin & 29 & 41 & 8.7 & 14.8 \\
\hline & $5 \mathrm{FU}$ without cisplatin & 41 & 17 & 3.9 & 12.0 \\
\hline Overman et al. .40$)$ & Capecitabine + oxaliplatin & 30 & 52 & 11.3 & 20.0 \\
\hline Zaanan et al. ${ }^{(41)}$ & FOLFIRI (second line) & 28 & 20 & 3.2 & 10.5 \\
\hline
\end{tabular}

5FU: 5-fluorouracil; MMC: mitomycin C; FOLFOX: 5-fluorouracil/leucovorin/oxaliplatin; LV5FU2: 5-fluorouracil/leucovorin; FOLFIRI: 5-fluorouracil/leucovorin/irinotecan.

Reprinted from: Aparicio et al., ${ }^{(10)}$ with permission from Elsevier.

Carcinoids are neuroendocrine tumors and upon diagnosis, $29 \%$ of cases are at a localized stage, $41 \%$ in a loco-regional stage, and $30 \%$ of patients present metastates. ${ }^{(42)}$ Of patients with midgut carcinoid tumors $40 \%$ have a second gastrointestinal neoplasm, which requires a careful diagnostic evaluation prior to surgery of these tumors. ${ }^{(43)}$ The rate of lymph node and distant metastases is 12 and 5\%, respectively, in tumor smaller than $1 \mathrm{~cm}$, and 85 and $47 \%$, respectively, for tumor greater than $2 \mathrm{~cm} .{ }^{(8)}$ Surgery represents the main approach for localized disease, with wide excision of the bowel and mesentery. Peritoneal carcinomatosis may be present in up to $30 \%$ of patients with small intestine primary neuroendocrine tumors. ${ }^{(4)}$ For carefully selected patients presenting neuroendocrine tumors-related peritoneal carcinomatosis, it seems that cytoreductive surgery prolongs survival, especially when peritoneal lesions are completed resected. ${ }^{(44)}$

\section{CONCLUSION}

Primary small bowel cancers are usually diagnosed at an advanced stage, and revealed by a local complication of the tumor. Their surgical approach in emergency setting carries specific morbidity and significant mortality, but only a standard radical $\mathrm{R} 0$ resection with regional lymph node dissection may provide the patients the best chance for cure.

\section{AUTHORS' CONTRIBUTIONS}

All authors made substantial intellectual contributions to the published study. All authors revised critically the manuscript. Negoi I - drafting the article; Hostiuc S, Paun S - concept and design of the study; Stoica B, Tanase I, Negoi RI - data gathering; Beuran $M$ - critical revision of the manuscript and final approval of the version to be published.

\section{REFERENCES}

1. Kummar S, Ciesielski TE, Fogarasi MC. Management of small bowel adenocarcinoma. Oncology (Williston Park). 2002;16(10):1364-9; discussion 1370, 1372-3. Review.

2. Overman MJ. Rare but real: management of small bowel adenocarcinoma. Am Soc Clin Oncol Educ Book. 2013:189-93.

3. Siegel RL, Miller KD, Jemal A. Cancer statistics, 2015. CA Cancer J Clin. 2015;65(1):5-29.

4. Khan K, Peckitt C, Sclafani F, Watkins D, Rao S, Starling N, et al. Prognostic factors and treatment outcomes in patients with Small Bowel Adenocarcinoma (SBA): the Royal Marsden Hospital (RMH) experience. BMC Cancer. 2015;15:15.

5. Hatzaras I, Palesty JA, Abir F, Sullivan P, Kozol RA, Dudrick SJ, et al. Smallbowel tumors: epidemiologic and clinical characteristics of 1260 cases from the connecticut tumor registry. Arch Surg. 2007;142(3):229-35.

6. Talamonti MS, Goetz LH, Rao S, Joehl RJ. Primary cancers of the small bowel: analysis of prognostic factors and results of surgical management. Arch Surg. 2002;137(5):564-70; discussion 570-1.

7. DiSario JA, Burt RW, Vargas H, McWhorter WP. Small bowel cancer: epidemiological and clinical characteristics from a population-based registry. Am J Gastroenterol. 1994;89(5):699-701.

8. Shenoy S. Primary small-bowel malignancy: update in tumor biology, markers, and management strategies. J Gastrointest Cancer. 2014;45(4):421-30. Review. 
9. Chen SC, Shyr YM, Wang SE. Long-term survival after pancreaticoduodenectomy for periampullary adenocarcinomas. HPB (Oxford). 2013;15(12):951-7.

10. Aparicio T, Zaanan A, Svrcek M, Laurent-Puig P, Carrere N, Manfredi S, et al. Small bowel adenocarcinoma: epidemiology, risk factors, diagnosis and treatment. Dig Liver Dis. 2014;46(2):97-104. Review.

11. Kopáčová M, Rejchrt S, Bureš J, Tachecí I. Small intestinal tumours. Gastroenterol Res Pract. 2013;2013:702536.

12. Chow WH, Linet MS, McLaughlin JK, Hsing AW, Chien HT, Blot WJ. Risk factors for small intestine cancer. Cancer Causes Control. 1993;4(2):163-9.

13. Günther $C$, Neumann $H$, Neurath MF, Becker C. Apoptosis, necrosis and necroptosis: cell death regulation in the intestinal epithelium. Gut. 2013;62(7): 1062-71. Review.

14. Sellner F. Investigations on the significance of the adenoma-carcinoma sequence in the small bowel. Cancer. 1990;66(4):702-15. Review.

15. Schottenfeld D, Beebe-Dimmer JL, Vigneau FD. The epidemiology and pathogenesis of neoplasia in the small intestine. Ann Epidemiol. 2009;19(1): 58-69. Review.

16. Canavan C, Abrams KR, Mayberry J. Meta-analysis: colorectal and small bowel cancer risk in patients with Crohn's disease. Aliment Pharmacol Ther. 2006;23(8):1097-104.

17. Green PH, Cellier C. Celiac disease. N Engl J Med. 2007;357(17):1731-43. Review.

18. Green PH, Stavropoulos SN, Panagi SG, Goldstein SL, Mcmahon DJ, Absan H, et al. Characteristics of adult celiac disease in the USA: results of a national survey. Am J Gastroenterol. 2001;96(1):126-31.

19. Vasen HF, Wijnen JT, Menko FH, Kleibeuker JH, Taal BG, Griffioen G, et al. Cancer risk in families with hereditary nonpolyposis colorectal cancer diagnosed by mutation analysis. Gastroenterology. 1996;110(4):1020-7. Erratum in: Gastroenterology. 1996;111(5):1402.

20. Kadmon M, Tandara A, Herfarth C. Duodenal adenomatosis in familial adenomatous polyposis coli. A review of the literature and results from the Heidelberg Polyposis Register. Int J Colorectal Dis. 2001;16(2):63-75. Review.

21. Giardiello FM, Brensinger JD, Tersmette AC, Goodman SN, Petersen GM, Booker SV, et al. Very high risk of cancer in familial Peutz-Jeghers syndrome. Gastroenterology. 2000;119(6):1447-53.

22. van der Flier LG, Clevers H. Stem cells, self-renewal, and differentiation in the intestinal epithelium. Annu Rev Physiol. 2009;71:241-60. Review.

23. Sun J. Enteric bacteria and cancer stem cells. Cancers (Basel). 2010;3(1):285-97.

24. Laforest A, Aparicio T, Zaanan A, Silva FP, Didelot A, Desbeaux A, et al. ERBB2 gene as a potential therapeutic target in small bowel adenocarcinoma. Eur $\mathrm{J}$ Cancer. 2014;50(10):1740-6.

25. Maglinte DD, O'Connor K, Bessette J, Chernish SM, Kelvin FM. The role of the physician in the late diagnosis of primary malignant tumors of the small intestine. Am J Gastroenterol. 1991;86(3):304-8.

26. Weiss NS, Yang CP. Incidence of histologic types of cancer of the small intestine. J Natl Cancer Inst. 1987;78(4):653-6.

27. Bilimoria KY, Bentrem DJ, Wayne JD, Ko CY, Bennett CL, Talamonti MS. Small bowel cancer in the United States: changes in epidemiology, treatment, and survival over the last 20 years. Ann Surgery. 2009;249(1):63-71.

28. Lu Y, Fröbom R, Lagergren J. Incidence patterns of small bowel cancer in a population-based study in Sweden: increase in duodenal adenocarcinoma. Cancer Epidemiol. 2012;36(3):e158-63.
29. Gabos S, Berkel J, Band P, Robson D, Whittaker H. Small bowel cancer in western Canada. Int J Epidemiol. 1993;22(2):198-206.

30. Howe JR, Karnell LH, Menck HR, Scott-Conner C. The American College of Surgeons Commission on Cancer and the American Cancer Society. Adenocarcinoma of the small bowel: review of the National Cancer Data Base, 1985-1995. Cancer. 1999;86(12):2693-706.

31. Sohn TA, Lillemoe KD, Cameron JL, Pitt HA, Kaufman HS, Hruban RH, et al. Adenocarcinoma of the duodenum: factors influencing long-term survival. J Gastrointest Surg. 1998;2(1):79-87.

32. Abrahams NA, Halverson A, Fazio VW, Rybicki LA, Goldblum JR. Adenocarcinoma of the small bowel: a study of 37 cases with emphasis on histologic prognostic factors. Dis Colon Rectum. 2002;45(11):1496-502.

33. Ogata Y, Yamaguchi K, Sasatomi T, Uchida S, Akagi Y, Shirouzu K. [Treatment and outcome in small bowel cancer]. Gan To Kagaku Ryoho. 2010;37(8):1454-7. Review. Japanese.

34. Czaykowski P, Hui D. Chemotherapy in small bowel adenocarcinoma: 10-year experience of the British Columbia Cancer Agency. Clin Oncol (R Coll Radiol). 2007;19(2):143-9.

35. Crawley C, Ross P, Norman A, Hill A, Cunningham D. The Royal Marsden experience of a small bowel adenocarcinoma treated with protracted venous infusion 5-fluorouracil. Br J Cancer. 1998;78(4):508-10.

36. Locher C, Malka D, Boige V, Lebray P, Elias D, Lasser $P$, et al. Combination chemotherapy in advanced small bowel adenocarcinoma. Oncology. 2005; 69(4):290-4.

37. Gibson MK, Holcroft CA, Kvols LK, Haller D. Phase II study of 5-fluorouracil, doxorubicin, and mitomycin $\mathrm{C}$ for metastatic small bowel adenocarcinoma. Oncologist. 2005;10(2):132-7.

38. Zaanan A, Costes L, Gauthier M, Malka D, Locher C, Mitry E, et al. Chemotherapy of advanced small-bowel adenocarcinoma: a multicenter AGEO study. Ann Oncol. 2010;21(9):1786-93.

39. Overman MJ, Kopetz S, Wen S, Hoff PM, Fogelman D, Morris J, et al. Chemotherapy with 5-fluorouracil and a platinum compound improves outcomes in metastatic small bowel adenocarcinoma. Cancer. 2008;113(8):2038-45.

40. Overman MJ, Varadhachary GR, Kopetz S, Adinin R, Lin E, Morris JS, et al. Phase II study of capecitabine and oxaliplatin for advanced adenocarcinoma of the small bowel and ampulla of Vater. J Clin Oncol. 2009;27(16):2598-603.

41. Zaanan A, Gauthier M, Malka D, Locher C, Gornet JM, Thirot-Bidault A, Tougeron D, Taïeb J, Bonnetain F, Aparicio T; Association des Gastro Entérologues Oncologues. Second-line chemotherapy with fluorouracil, leucovorin, and irinotecan (FOLFIRI regimen) in patients with advanced small bowel adenocarcinoma after failure of first-line platinum-based chemotherapy: a multicenter AGE0 study. Cancer. 2011;117(7):1422-8.

42. Strosberg J. Neuroendocrine tumours of the small intestine. Best Pract Res Clin Gastroenterol. 2012;26(6):755-73. Review.

43. Moertel CG, Sauer WG, Dockerty MB, Baggenstoss AH. Life history of the carcinoid tumor of the small intestine. Cancer. 1961;14:901-12.

44. de Mestier L, Lardière-Deguelte S, Brixi H, O’Toole D, Ruszniewski P, Cadiot G, et al. Updating the surgical management of peritoneal carcinomatosis in patients with neuroendocrine tumors. Neuroendocrinology. 2015;101(2):105-11. 